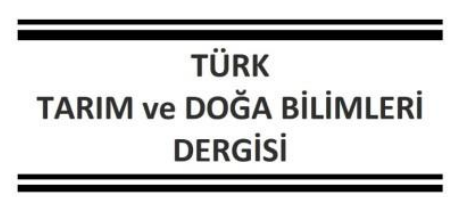

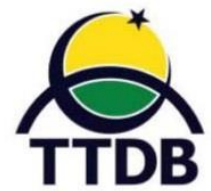

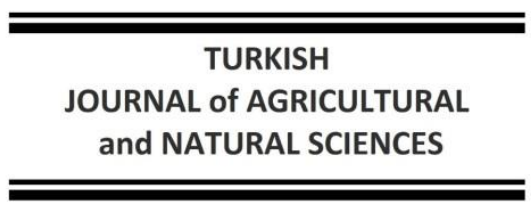

www.dergipark.gov.tr/turkjans

Research Article

\title{
Determination of The Suitability to European Union and Turkish Standards of Fat Ratios in Cow Milk Obtained from Kirklareli Province
}

\author{
A. Burcu ATALAY ${ }^{1 *}$, Murat ÇiMEN² \\ ${ }^{1}$ ğgır University, Vocational School of Iğdır, Department of Hotel, Restaurant and Catering, Program in Cookery, \\ Iğdır \\ ${ }^{2}$ Munzur University, Vocational School of Tunceli, Department of Plant and Animal Production, Organic \\ Agriculture Program, Tunceli \\ *Sorumlu Yazar: aburcu.atalay@igdir.edu.tr
}

Received: 22.03.2021 Received in revised: 20.09.2021 Accepted: 13.10.2021

\begin{abstract}
In this study, it was aimed to determine the suitability of the total fat means of milk obtained from cows raised in Kırklareli province with reference values of European Union (EU) and Turkish Standards (TS) during the summer season. For this purpose, the fat means obtained were compared with the reference values required for both standards with the help of the one-sample T-test. It has been determined that the fat content of milk obtained from Kırklareli province is not in compliance with EU and Turkish Standards. It was observed that an average value below the minimum level specified in the said standards (EU reference value at least $3.6 \%$, TS reference value at least $3.5 \%)$ was obtained $(P<0.01)$. Fat mean $(3.02 \%)$ of cow milk obtained from Kırklareli province during the summer season was not found suitable and healthful also economical for the production of milk and milk products for Turkish and EU Standards. In order to eliminate this disadvantage, appropriate feeding programs should be prepared and environmental conditions should be taken into consideration in order to increase the milk fat ratio of cows raised in Kırklareli Province of Turkey.
\end{abstract}

Keywords: Cow, Milk, Fat, Standard

\section{Kırklareli İlinden Elde Edilen İnek Sütünün Yağ Oranlarının Avrupa Birliği ve Türkiye Standartlarına Uygunluğunun Belirlenmesi}

\section{Öz}

Bu çalışmada, yaz sezonunda Kırklareli ilinde yetiştirilen ineklerden elde edilen sütün toplam yağ oranının Avrupa Birliği (AB) referans değerlerine ve Türk Standartlarına (TS) uygunluğunun belirlenmesi amaçlanmıştır.Bu amaçla elde edilen yağ ortalamaları her iki standart için gerekli olan referans değerlerle tek örnek T-testi yardımıyla karşılaştııılmışır.Kırklareli ilinden elde edilen sütün yağ içeriğinin $A B$ ve Türk Standartlarına uygun olmadığı tespit edilmiştir.Söz konusu standartlarda belirtilen minimum düzeyin altında ortalama bir değerin ( $A B$ referans değeri en az \% 3.6, TS referans değeri en az \% 3.5) elde edildiği görülmüştür $(P<0.01)$.Kırklareli ilinden yaz sezonu boyunca elde edilen inek sütünün yağ ortalaması (\% 3.02) Türkiye ve $A B$ standartlarına göre süt ve süt ürünleri üretimi için uygun ve ekonomik olmadığı bulunmuştur. Bu dezavantajı ortadan kaldırmak için Türkiye'nin Kırklareli ilinde yetiştirilen ineklerin süt yağ oranını artırmak için uygun yemleme programları hazırlanmalı ve çevresel koşullar göz önüne alınmalıdır.

Anahtar kelimeler: İnek, Süt, Yağ, Standart 


\section{Introduction}

Milk contains the nutrients needed by the body in every period of human life, is easily available, and is indispensable for the consumer. The European Union (EU), while the average annual milk yield of dairy cows in the country amounts to 4800 liters of average production in Turkey is around 1700 liters (Anonim, 2007). One of the reasons for the high production in EU countries is the density of industrial facilities where milk will be processed and the high earnings of the producers as a result of the compliance of the raw milk to be processed in these facilities with EU standards. For this reason, regarding the fact that the total fat ratio in milk should not fall below the specified EU and Turkish Standard value; necessary precautions should be taken and especially milk producers should be informed. Also, it is of great importance because milk fat contains many nutrients such as fat-soluble vitamins, energy, and bioactive lipids that are necessary for humans (van Arendonk et al., 2010). Food products have numerous benefits of milk fat. The mechanical properties of dairy fat products are influenced by the crystal structure of milk fat as well as the nutritional value, desired mouthfeel,and flavor properties (Ramel and Marangoni, 2019). Milk fat is also an important component of bioactive fatty acid conjugated linoleic acid in the human diet. Conjugated linoleic acid exhibits important health benefits such as anticarcinogenic, antiatherogenic, immunomodulating, and antiobesity impacts (Mortensen, 2016).

In the recently developed countries in milk pricing, the emphasis is on the ratio of milk fat and protein. Especially in European countries, the total fat and protein content in milk is traditionally taken into account in the mechanisms that cause the price of milk, and it also plays an important role in determining the prices of milk powder, butter (milk fat) cheese, and raw milk prices (Anonymous, 2007). In our country, which is an EU candidate, it is expected that pricing will be made according to milk composition in the future. The synthesis of milk parameters is determined by the genetic makeup of the animal and environmental conditions (Remeuf et al., 1991). For this reason, there is a need for studies that will determine reference values in different environmental conditions on total milk fat and protein, which have economic importance in milk (Yıldırım and Cimen, 2009; Çetin et al; 2010; Tekelioğlu et al., 2010). In this study, it is aimed to reach comments on whether the mean fat values of milk obtained from cows raised in Kırklareli province are in accordance with EU and Turkish standards.

\section{Material and Methods}

\section{Data collection}

In this research, daily total fat means (for 82 samples) in cow milk collected from a private dairy farm in Kırklareli province during the summer season were analyzed. In the research, the data obtained as a result of the analysis of the milk collected daily in June and brought to a private dairy farm in tanks were used.

\section{Milk analysis}

Total fat ratios in milk were measured with Milkana Superior Milk Analyzer (with datamemory) device.10 $\mathrm{ml}$ of daily milk sample was placed in the sterile sample container and after 90 seconds the device gave the relevant results in \%. Daily obtained milk fat means were recorded.

\section{Statistical analysis}

One sample T-test method was used to compare the obtained milk fat mean with reference values of the EU (Anonymous, 2007) and Turkish Standard (Anonymous, 1981). SPSS package program was used in the implementation of the mentioned statistical analysis method (Norusis, 1993; Çimen, 2015). Reference values given in Table 1 were used to determine the conformity for the EU and Turkish Standards.

Before the obtained data were analyzed, their suitability for normal distribution was examined. It was tried to determine whether the data are parametric or non-parametric (Cimen, 2016).

\section{Results and Discussion}

Mean fat values of milk obtained from cows raised in Kırklareli province were compared with the standard reference values specified in Table 1. The distribution of obtained milk fat values was determined parametrically. The statistical analysis results of the one-sample T-test (parametric test), which was made to find out the conformity of milk fat rates with the reference values, are given in Tables 2 and 3.

When tables 2 and 3 are examined, it is seen that the obtained milk fat values are lower than the reference values when the average milk fat values with the reference values specified for EU and TS are compared. Therefore, it can be said that the fat values of cow's milk obtained from Kırklareli province were not found suitable for both standards (EU and TS). In the study, the found mean fat level for Kırklareli province (3.02\%) showed lower average value compared to the 
results (3.64\%) of Karakoç et al. (2013). The obtained findings from the study of Karakoc et al.
(2013) include the results of Batman province.

Table 1. Milk reference values in Turkish Standarts (Anonymous, 1981) and European Union (Anonymous, 2007)

\begin{tabular}{lll}
\hline Reference values & TS & AB \\
\hline Minimum Fat, \% & 3.5 & 3.6 \\
\hline
\end{tabular}

Table 2. Milk fat statistical analysis for Turkish Standards

\begin{tabular}{l|l|l|l|l}
\hline \multicolumn{3}{l}{ One-Sample Statistics } \\
\hline \multirow{2}{*}{ Milk fat } & $\mathrm{N}$ & Mean & Std. Deviation & Std. Error Mean \\
\cline { 2 - 5 } & 82 & 3.0214 & .23467 & .05003 \\
\hline
\end{tabular}

One-Sample T-Test

Test Value $=3.5$

\begin{tabular}{|c|c|c|c|c|c|c|}
\hline & \multirow{2}{*}{$\mathrm{t}$} & \multirow{2}{*}{$d f$} & \multirow{2}{*}{ Sig. (2-tailed) } & \multirow{2}{*}{ Mean Difference } & \multicolumn{2}{|c|}{$95 \%$ Confidence Interval of the Difference } \\
\hline & & & & & Lower & Upper \\
\hline Milk fat & -9.567 & 81 & .000 & -.47864 & -.5827 & -.3746 \\
\hline
\end{tabular}

Table 3. Milk fat statistical analysis for European Union Standards

One-Sample Statistics

\begin{tabular}{lllll}
\hline & $\mathrm{N}$ & Mean & Std. Deviation & Std. Error Mean \\
\cline { 2 - 4 } Milk fat & 82 & 3.0214 & .23467 & .05003 \\
\hline
\end{tabular}

One-Sample T-Test

Test Value $=3.6$

95\% Confidence Interval of the Difference

\begin{tabular}{lllllll} 
& $\mathrm{t}$ & $\mathrm{df}$ & Sig. (2-tailed) & Mean Difference & Lower & Upper \\
\cline { 2 - 6 } Milk fat & -11.56 & 81 & .000 & -.57864 & -.6827 & -.4746 \\
\hline
\end{tabular}

The difference between the averages of fat in the afore-mentioned research and the found fat values in our research is based on years, business, nutrition, etc. factors such as may have been effective. The obtained results from Kırklareli province in our study forthe summer season are not satisfactory in terms of the dairy industry. It will be useful to examine and determine the factors that cause the low mean values of the parameter in question.

Galli and Rise (2017) reported that during summer milk fat percentages can be lower than during winter and because of the higher temperatures fatty acid composition can differ, so seasonal changes affect milk fat percentages. Changes in the percentage of milk fat can occur due to differences in the environmental conditions or nutrient intake (Bauman et al., 2011).
Maximizing the earnings of the dairy cattle breeding enterprises in Kırklareli province is essential for the continuity of the production of the enterprises. For this province, attention should be paid to animal feeding activities. Because there is a relationship between animal feeding and milk fat levels (Fuller, 2004). However, when a purchasing policy based on fat is applied in the current situation, Kırklareli province has a significant disadvantage. Studies on the determination of milk parameter values having economic importance such as fat in our country have gained intensity recently (Ablak et al., 2013; Çimen et al., 2011; Çimen and Tekelioğlu, 2011; Eryılmaz et al., 2012). Therefore, new studies are needed to determine reference values of milk parameters on a provincial basis with results obtained from different periods and different enterprises in many provinces in our 
country. With the found reference values and the reference value maps to be created accordingly, it will be possible to determine the advantages and disadvantages of the provinces in the future improvement studies based on regions and provinces, supports to be made according to biochemical parameters and raw material purchases. Besides, with the preparation of these maps, an advantage will be obtained in terms of obtaining preliminary information on many issues such as taking measures to optimize the fat values that are seen to be insufficient according to the provinces and evaluating the emergency response priorities according to the provinces.

Conflict of Interest: The authors declare no conflict of interest.

Contribution Rate Statement Summary: The authors declare that they have contributed equally to the article.

\section{References}

Ablak, E., Çimen, M., Karakoç,D., Yılmaz, M., Yıldız, R. veYılmaz,í. 2013. Batman ilinden elde edilen sütlerde toplam yağın türk ve avrupa birliği standartlarına uygunluğunun belirlenmesi. Bilim ve Gençlik Dergisi, 1(1): 25-30.

Anonim,1981. Çiğ Süt Standardı. TS 1018. Türk Standartları Enstitüsü. Ankara.

Anonim,2007. AB Giriş süreci çerçevesinde türkiye'de süt ve süt ürünleri sektörüne genel bakış.FAO Avrupa ve Orta Asya Bölge Ofisi Politika Yardımları Şubesi. Birleşmiş Milletler Gıda Ve Tarım Örgütü, Roma, 105 S.

Bauman, D.E., McGuire, M.A. andHarvatine, K.J. 2011. Mammary Gland, Milk Biosynthesis, and Secretion I Milk Fat.Encyclopedia of Dairy Sciences (Second Edition), 352-358 s.

Cetin, M., Cimen, M., Goksoy, E.O. and Yildirim,S. 2010. Machine milked and suckled goats differ in some biochemical components of their milk in 1st and 2nd Weeks of Lactation, Int. J. Agric. Biol., 12 (5) : 799800.

Çimen, M. 2015. Fen ve Sağlık Bilimleri Alanlarında Spss uygulamalı Veri Analizi. Palme Yayıncılık, Yayın No: 905, ISBN: 978-605355-366-3. Sıhhıye, Ankara.

Çimen, M.2016.Mühendislik verilerinde tek örnek için parametrik ve parametrik olmayan testler.İstanbul Aydın Üniversitesi Dergisi, 29 : 67-77.

Çimen, M., Güven, A., ve Gayretli, D. 2011. Diyarbakır ilinden elde edilen inek sütlerinde ekonomik öneme sahip biyokimyasal parametrelerin standartlara uygunluğunun belirlenmesi. 7. Ulusal Zootekni Bilim Kongresi. 14-16 Eylül. Adana.

Çimen, M. veTekelioğlu, O. 2011. Tokat ilinde makineli sağımla elde edilen inek sütlerinde total yağın türk ve avrupa birliği standartlarına uygunluğunun belirlenmesi. Karaelmas Fen ve Mühendislik Dergisi, 1 (2) : 45-48.

Eryılmaz, H., Çimen, M., Eryılmaz, M., Özer,A. Ve Karataş,S. 2012. Elazığ ilinden mart ayında elde edilen inek sütlerinde ekonomik öneme sahip biyokimyasal parametrelerin ab ve türk standartlarına uygunluğunun belirlenmesi. Gıda Teknolojileri Elektronik Dergisi, 7(2) : 44-47.

Fuller, M.F.2004. The Encyclopedia of Farm Animal Nutrition. $\mathrm{CABI}$ Publishing. $\mathrm{CAB}$ International Wallingford. OXON UK. ISBN: 0 85199369 9, $621 \mathrm{~s}$.

Galli, C., and Risé, P. 2017. The role of fats in milk and dairy products in nutrition and health from infancy to adulthood. Dairy in Human Health and Disease Across the Lifespan, (4): 57-72.

Karakoç, D., Çimen, M., Demir, N., Şos, C., Gökyer, H.,Ablak,E., ve Kutlu, C. 2013. Ağustos ve kasım aylarında batman ilinden elde edilen sütlerde ekonomik öneme sahip biyokimyasal parametreler. Bilim ve Gençlik Dergisi, 1(1) :19-23.

Mortensen, B.K. 2016.Butter and Other Milk Fat Products/Modified Butters.Reference Module in Food Science, Encyclopedia of Dairy Sciences, 500-505 s.

Norusis, M.J.1993.SPSS for Windows:Base System User's Guide.SPSS, Chicago.

Ramel, P.R. andMarangoni, A.G. 2019. The microstructure of Dairy Fat Products.Encyclopedia of Food Chemistry, 39-46.

Remeuf, F., Cossin, V., Dervin, C., Lenoir, J. and Tomassone,R. 1991. Relationship between physicochemical characteristics of milk and their cheese-making properties. Lait, 7 (1) :397-411.

Tekelioglu, O., Cimen, M.,Soylu, D. and Soylu, I. 2010. Milk components from machine milking cows in winter and spring periods.J. Anim. Vet. Adv.,9 (4) : 795-797.

Van Arendonk, J.A.M., van Valenberg, H.J.F., and Bovenhuis, H. 2010. Exploiting genetic variation in the milk-fat composition of milk from dairy cows. Improving the Safety and 
Quality of Milk: Milk Production and Processing,197-222.

Yildirim, S. and Cimen, M. 2009. Biochemical factors affecting the taste of milk from machine milking.Asian J. Chem., 21(3): 2457- 2460. 